\title{
Sequence analysis reveals mosaic genome of Aichi virus
}

\author{
Xiaohong $\mathrm{Han}^{\dagger}$, Wen Zhang ${ }^{*}{ }^{\dagger}$, Yanjun Xue and Shihe Shao
}

\begin{abstract}
Aichi virus is a positive-sense and single-stranded RNA virus, which demonstrated to be related to diarrhea of Children. In the present study, phylogenetic and recombination analysis based on the Aichi virus complete genomes available in GenBank reveal a mosaic genome sequence [GenBank: FJ890523], of which the nt 261-852 region (the nt position was based on the aligned sequence file) shows close relationship with AB010145/Japan with $97.9 \%$ sequence identity, while the other genomic regions show close relationship with AY747174/German with $90.1 \%$ sequence identity. Our results will provide valuable hints for future research on Aichi virus diversity. Aichi virus is a member of the Kobuvirus genus of the Picornaviridae family $[1,2]$ and belongs to a positive-sense and single-stranded RNA virus. Its presence in fecal specimens of children suffering from diarrhea has been demonstrated in several Asian countries [3-6], in Brazil and German [7], in France [8] and in Tunisia [9]. Some reports showed the high level of seroprevalence in adults [7,10], suggesting the widespread exposure to Aichi virus during childhood.

The genome of Aichi virus contains 8,280 nucleotides and a poly(A) tail. The single large open reading frame (nt 713-8014 according to the strain AB010145) encodes a polyprotein of 2,432 amino acids that is cleaved into the typical picornavirus structural proteins VPO, VP3, VP1, and nonstructural proteins 2A, 2B, 2C, 3A, 3B, 3C and 3D $[2,11]$. Based on the phylogenetic analysis of 519-bp sequences at the 3C-3D (3CD) junction, Aichi viruses can be divided into two genotypes A and B with approximately $90 \%$ sequence homology [12]. Although only six complete genomes of Aichi virus were deposited in GenBank at present, mosaic genomes can be found in strains from different countries.
\end{abstract}

\section{Methods}

\section{Sequences}

The study sequences comprised six available complete genome sequences of Aichi virus from GenBank dated May 2011, including three Japan strains [GenBank: FJ890523, GenBank: NC_001918, GenBank: AB010145], one German strain [GenBank: AY747174], one Brazil strain [GenBank: DQ028632] and one China strain [GenBank: FJ890523]. Sequences were firstly screened to exclude patented and artificial mutants, and then aligned in the ClustalW program [13]. The alignment was manually adjusted for the correct reading frame. Sequences showing less than $1 \%$ divergence from each other were considered as the same. The remaining five

\footnotetext{
* Correspondence: z0216wen@yahoo.com

+ Contributed equally

School of Medical Science and Laboratory Medicine, Jiangsu University, 301 Xuefu Road, Zhenjiang, Jiangsu 212013, PR China
}

genomes include two Japan strains, one German strain, one Brazil strain and one China strain.

\section{Phylogenetic Analysis and Recombination Detection}

Before phylogenetic analysis, multiple-alignment was performed in the ClustalW program (http://www.clustal. org/). Phylogenetic trees were constructed using the neighbor-joining method and evaluated using the interior branch test method with Mega 4 software [14]. Percent bootstrap support was indicated at each node. GenBank accession no. was indicated at each branch. Detection of potential recombinant sequences, identification of potential parental sequences, and localization of possible recombination break points were determined using the Recombination Detection Program (RDP)[15], GENECONV [16], BOOTSCAN [17], MaxChi [18], CHIMAERA [19], and SISCAN [20] methods embedded in RDP3 [21]. A Multiple-comparison-corrected P-value cutoff of 0.05 was used throughout.

\section{Biomed Central}




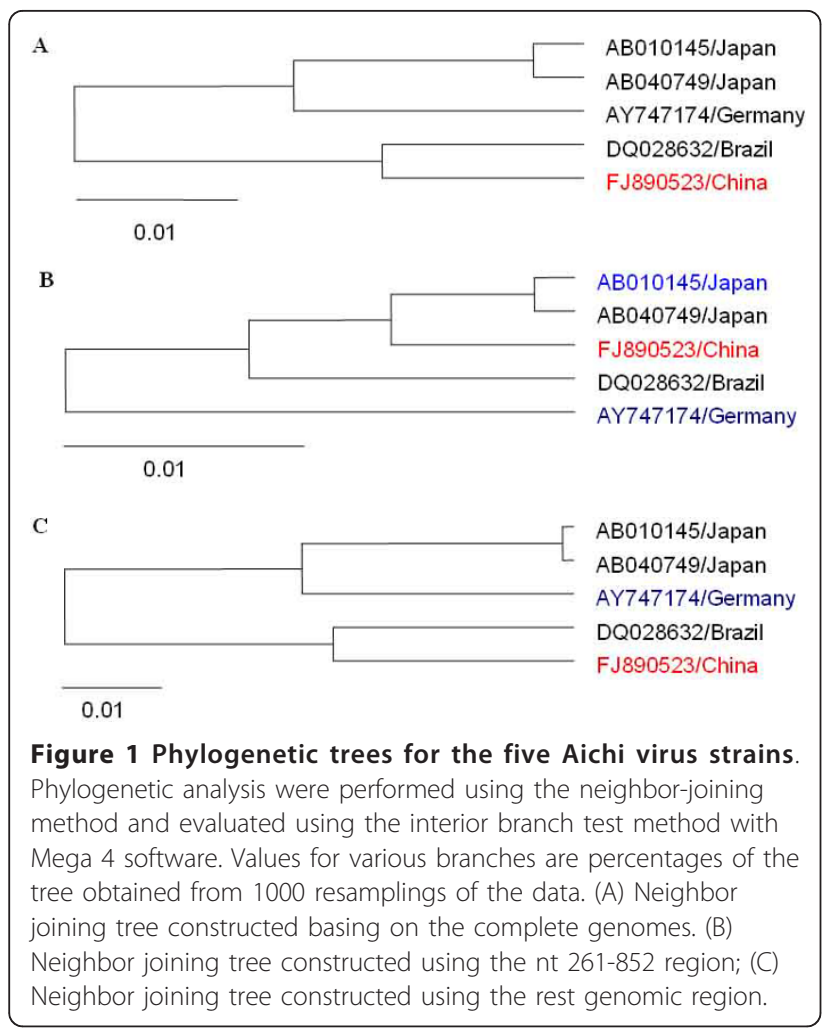

\section{Results and Discussion}

Based on the five complete genomes, a phylogenetic tree was constructed (Figure 1A). From the phylogenetic tree, we can see the five Aichi virus strains separated into two clusters. The two Japan Aichi virus strains [GenBank: AB010145, GenBank: AB040749] were closely related to the German strain [GenBank: AY747174] and formed into one cluster; while the Brazil [GenBank: DQ028632] and China Aichi virus strains [GenBank: FJ890523] clustered together, forming the other cluster.
Figure 2 indicated the Bootscan plots showing the likehood of recombinant sequence [GenBank: FJ890523], of which the nt 261-852 region shows close relationship with Japanese strain [GenBank:AB010145], while the other genomic regions show close relationship with the German strain [GenBank:AY747174]. The Bootscan results suggested that genome of Chinese Aichi virus strain [GenBank: FJ890523] was mosaic. This inference was confirmed by phylogenetic analysis, where two discordant phylogenetic relationship were showed in Figure $1 \mathrm{~B}$ and $1 \mathrm{C}$. Figure $1 \mathrm{~B}$ indicated the tree constructed over the nt 261-852 region, where the Chinese strain [GenBank: FJ890523] was more closely related to the two Japan Aichi virus strains than to Brazil and German strains. Figure $1 \mathrm{C}$ indicated the tree established on the on the rest genomic region, which was similar to that constructed basing on the whole genome sequence, where the Chinese strain [GenBank: FJ890523] showed more closely to Brazil strain than to the other strains. Figure 3 indicated the pairwise identity between the Chinese strain [GenBank: FJ890523], German strain [GenBank: AY747174], and Japanese strain [GenBank: AB010145], which provide further evidence that mosaiclike genome exists in Aichi virus strain [GenBank: F)890523].

Due to the limited numbers of Aichi virus sequence available at present days, the parental strains of the mosaic Aichi virus strain have not been identified in the present study. However, we think with the increasing number of Aichi virus genome, further study should be performed to elucidate whether accurate recombination event can happen between different Aichi virus strains. Because recombination is a relatively common phenomenon in positive-sense RNA viruses [22-24] and understanding recombination can be helpful in unravelling the evolution of pathogens and drug resistance.

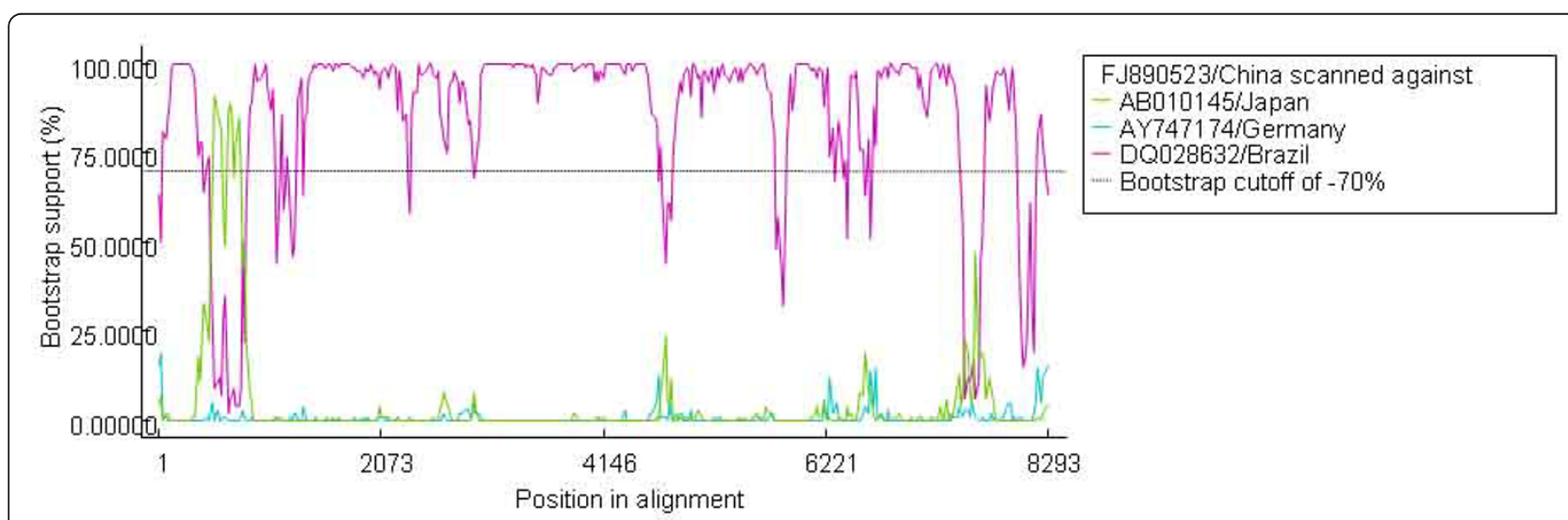

Figure 2 Bootscan plots using sequence of the Chinese Aichi virus strain [GenBank: FJ890523] with Japanses Aichi virus strain [GenBank: AB010145] and German Aichi virus strain [GenBank: Y747174]. The analysis was performed on the basis of pairwise distance, modeled with a window size 200, step size 20, and 100 Bootstrap replicates; 


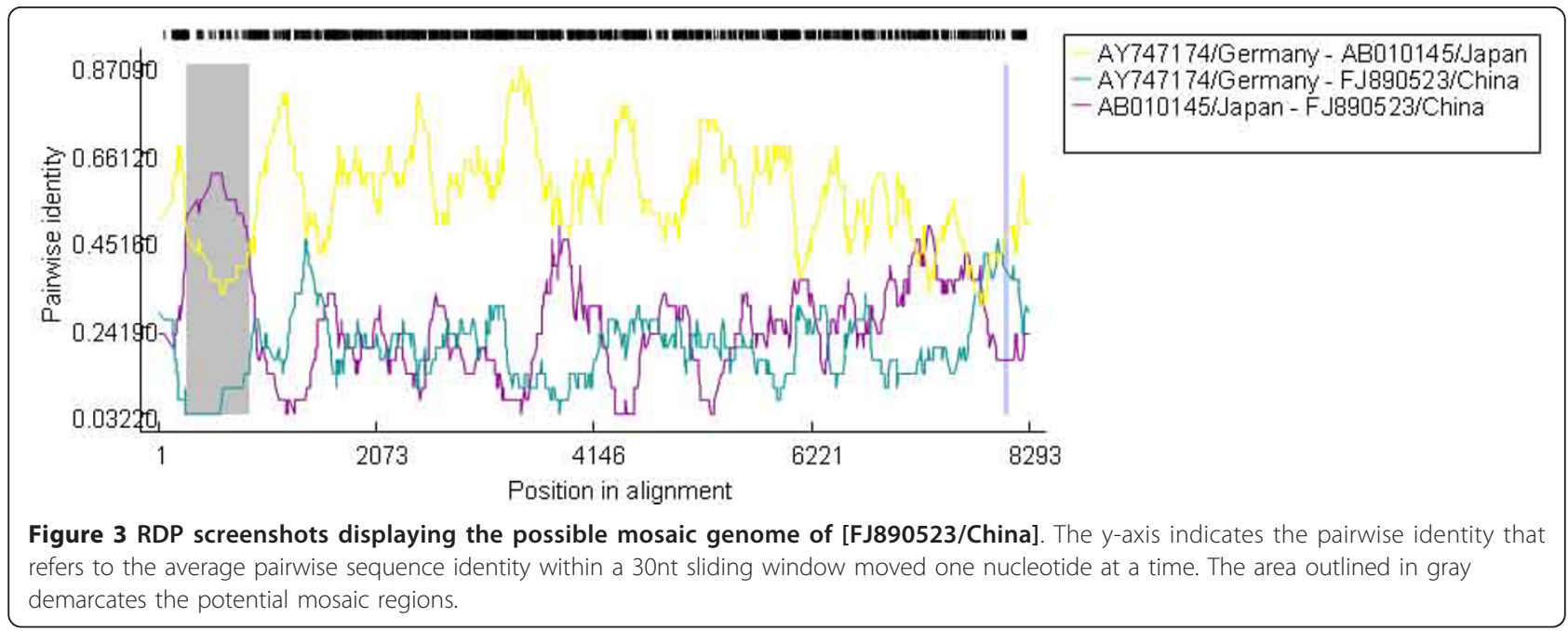

\section{Conclusion}

Taken together, this study reveals a mosaic genome sequence of Aichi virus [GenBank: FJ890523], of which the nt 261-852 region shows close relationship with strain of AB010145/Japan, while the other genomic regions show close relationship with German strain [GenBank:AY747174].

\section{Acknowledgements}

This work was supported by the Professional Research Foundation for Advanced Talents of Jiangsu University under Grant No.10JDG059.

\section{Authors' contributions}

XH and WZ conceived the study. All authors performed recombination analysis and critically reviewed and approved the final manuscript. WZ and $\mathrm{XH}$ wrote the paper. All authors read and approved the final manuscript

\section{Competing interests}

The authors declare that they have no competing interests.

Received: 23 May 2011 Accepted: 5 August 2011

Published: 5 August 2011

\section{References}

1. Pringle C: Virus taxonomy at the XIth International Congress of Virology, Sydney, Australia, 1999. Arch Virol 1999, 144:2065-70.

2. Yamashita T, Sakae K, Tsuzuki H, Suzuki Y, Ishikawa N, Takeda N, Miyamura T, Yamazaki S: Complete nucleotide sequence and genetic organization of Aichi virus, a distinct member of the Picornaviridae associated with acute gastroenteritis in humans. J Virol 1998, 72:8408-12.

3. Pham NT, Khamrin P, Nguyen TA, Kanti DS, Phan TG, Okitsu S, Ushijima H: Isolation and molecular characterization of Aichi viruses from fecal specimens collected in Japan, Bangladesh, Thailand, and Vietnam. J Clin Microbiol 2007, 45:2287-8.

4. Yamashita T, Sakae K, Kobayashi S, Ishihara Y, Miyake T, Mubina A, Isomura S: Isolation of cytopathic small round virus (Aichi virus) from Pakistani children and Japanese travelers from Southeast Asia. Microbiol Immunol 1995, 39:433-5.

5. Yang S, Zhang W, Shen Q, Yang Z, Zhu J, Cui L, Hua X: Aichi virus strains in children with gastroenteritis, China. Emerg Infect Dis 2009, 15:1703-1705.

6. Verma H, Chitambar SD, Gopalkrishna V: Circulation of Aichi virus genotype B strains in children with acute gastroenteritis in India. Epidemiol Infect 2011
7. Oh D, Silva P, Hauroeder B, Diedrich S, Cardoso D, Schreier E: Molecular characterization of the first Aichi viruses isolated in Europe and in South America. Arch Virol 2006, 151:1199-206.

8. Ambert-Balay K, Lorrot M, Bon F, Giraudon H, Kaplon J, Wolfer M, Lebon P, Gendrel D, Pothier P: Prevalence and genetic diversity of Aichi virus strains in stool samples from community and hospitalized patients. $J$ Clin Microbiol 2008, 46:1252-8.

9. Sdiri-Loulizi K, Gharbi-Khélifi H, de Rougemont A, Chouchane S, Sakly N, Ambert-Balay K, Hassine M, Guédiche MN, Aouni M, Pothier P: Acute infantile gastroenteritis associated with human enteric viruses in Tunisia. J Clin Microbiol 2008, 46:1349-55.

10. Yamashita T, Sakae K, Ishihara Y, Isomura S, Utagawa E: Prevalence of newly isolated, cytopathic small round virus (Aichi strain) in Japan. J Clin Microbiol 1993, 31:2938-43.

11. Sasaki J, Kusuhara Y, Maeno Y, Kobayashi N, Yamashita T, Sakae K, Takeda N, Taniguchi K: Construction of an infectious CDNA clone of Aichi virus (a new member of the family Picornaviridae) and mutational analysis of a stem-loop structure at the $5^{\prime}$ end of the genome. J Virol 2001, 75:8021-30.

12. Yamashita T, Sugiyama M, Tsuzuki H, Sakae K, Suzuki Y, Miyazaki Y: Application of a reverse transcription-PCR for identification and differentiation of Aichi virus, a new member of the Picornavirus family associated with gastroenteritis in humans. J Clin Microbiol 2000, 38:2955-61.

13. Thompson JD, Higgins DG, Gibson TJ: CLUSTAL W: improving the sensitivity of progressive multiple sequence alignment through sequence weighting, position-specific gap penalties and weight matrix choice. Nucleic Acids Res 1994, 22:4673-4680.

14. Tamura K, Dudley J, Nei M, Kumar S: MEGA4: Molecular evolutionary genetics analysis (MEGA) software version 4.0. Mol Biol Evol 2007, 24:1596-1599.

15. Martin D, Rybicki E: RDP: detection of recombination amongst aligned sequences. Bioinformatics 2000, 16:562-563.

16. Padidam M, Sawyer S, Fauquet CM: Possible emergence of new geminiviruses by frequent recombination. Virology 1999, 265:218-225.

17. Martin DP, Posada D, Crandall KA, Williamson C: A modified bootscan algorithm for automated identification of recombinant sequences and recombination breakpoints. AIDS Res Hum Retrovir 2005, 21:98-102.

18. Smith JM: Analyzing the mosaic structure of genes. J Mol Evol 1992, 34:126-9.

19. Posada D, Crandall KA: Evaluation of methods for detecting recombination from DNA sequences: computer simulations. Proc Nat Acad Sci USA 2001, 98:13757-13762.

20. Gibbs MJ, Armstrong JS, Gibbs AJ: Sister-scanning: a Monte Carlo procedure for assessing signals in recombinant sequences. Bioinformatics 2000, 16:573-582.

21. Martin DP, Williamson C, Posada D: RDP2: recombination detection and analysis from sequence alignments. Bioinformatics 2005, 21:260-262. 
22. Malim MH, Emerman M: HIV-1 sequence variation: drift, shift, and attenuation. Cell 2001, 104:469-474.

23. Simmonds P: Recombination and selection in the evolution of picornaviruses and other Mammalian positive-stranded RNA viruses. $J$ Virol 2006, 80:11124-1140.

24. Liu W, Zhai J, Liu J, Xie Y: Identification of recombination between subgenotypes IA and IB of hepatitis A virus. Virus Genes 2010, 40:222-224.

doi:10.1186/1743-422X-8-390

Cite this article as: Han et al: Sequence analysis reveals mosaic genome of Aichi virus. Virology Journal 2011 8:390.

Submit your next manuscript to BioMed Central and take full advantage of:

- Convenient online submission

- Thorough peer review

- No space constraints or color figure charges

- Immediate publication on acceptance

- Inclusion in PubMed, CAS, Scopus and Google Scholar

- Research which is freely available for redistribution 